\title{
PERAN BRAND IMAGE MEMEDIASI PENGARUH KUALITAS PRODUK TERHADAP NIAT BELI ULANG
}

\author{
Made Nafshya Ananda Putri ${ }^{1}$ \\ I Putu Gde Sukaatmadja ${ }^{2}$
}

\author{
${ }^{1,2}$ Fakultas Ekonomi dan Bisnis Universitas Udayana (Unud), Bali, Indonesia \\ e-mail: nafshya96@gmail.com
}

\begin{abstract}
ABSTRAK
Niat beli ulang merupakan tindakan konsumen untuk membeli kembali suatu produk karena adanya kepuasan yang diterima setelah pembelian sebelumnya, agar konsumen merasa puas suatu perusahaan perlu memperhatikan faktor-faktor yang mempengaruhi niat untuk membeli ulang. Penelitian ini bertujuan untuk mengetahui peran brand image memediasi pengaruh kualitas produk terhadap niat beli ulang pada sepatu merek Adidas di Kota Denpasar. Penelitian ini dilakukan di wilayah Kota Denpasar dengan menyebarkan 120 kuesioner. Metode pengumpulan data yang digunakan adalah metode purposive sampling. Pengumpulan data dilakukan melalui penyebaran kuesioner secara online dan offline di lapangan. Teknik analisis yang digunakan adalah analisis jalur. Berdasarkan hasil penelitian menunjukan bahwa kualitas produk berpengaruh positif dan signifikan terhadap brand image. Kualitas produk berpengaruh positif dan signifikan terhadapniat beli ulang. Brand image berpengaruh positif dan signifikan terhadapniat beli ulang. Brand image sebagai variabel mediasi berpengaruh signifikan melalui kualitas produk terhadap niat beli ulang secara parsial.
\end{abstract}

Kata Kunci: brand image, kualitas produk, niat beli ulang.

\begin{abstract}
Repurchase intention is a consumer action to buy back a product because of the satisfaction received after the previous purchase, so that consumers feel satisfied a company needs to pay attention to the factors that affect the repurchase intention. This study aims to determine the role of brand image to mediate the effect of product quality on the re-purchase intention on Adidas brand shoes in Denpasar City. This research was conducted in Denpasar City area by disseminating 120 questionnaires. Data collection method used is purposive sampling method. Data collection is done through the spread of questionnaires online and offline in the field. The analysis technique used is path analysis. Based on the results of research show that product quality have positive and significant effect to brand image. Product quality has a positive and significant effect on the repurchase intention. Brand image has a positive and significant effect on the repurchase intention. Brand image as a mediation variable has significant effect through product quality to repurchase intention by partial.
\end{abstract}

Keywords: brand image, product quality, repurchase intention. 


\section{PENDAHULUAN}

Pertumbuhan ekonomi dan perkembangan bisnis di Indonesia terus meningkat. Dewasa ini, teknologi mengalami perkembangan yang sangat pesat dalam segala bidang (Wijaya dan Jasfar, 2014). Kemajuan teknologi membawa berbagai perubahan dalam kehidupan masyarakat yang meliputi pola pikir, gaya hidup dan munculnya berbagai kebutuhan masyarakat yang semakin beragam. Perubahan teknologi menyebabkan persaingan bisnis antar perusahaan semakin ketat.

Perusahaan dituntut untuk terus meningkatkan kualitas produk dan terus berinovasi menciptakan berbagai macam inovasi produk yang mampu memenuhi kebutuhan dan keinginan dari masyarakat. Perusahaan perlu mempelajari dan mengidentifikasi faktor-faktor yang akan mengarahkan perusahaan untuk sukses Fouladivanda et al. (2013). Perusahaan harus dapat memberikan kualitas yang sesuai dengan kebutuhan dan keinginan konsumen dengan memperhatikan standar-standar kualitas pasar yang ada Puspita dkk. (2016). Alasan untuk meningkatkan kualitas produk dapat ditunjukan untuk mempertahankan eksistensi suatu perusahaan bahkan agar dapat memenangkan persaingan bisnis. Salah satunya adalah persaingan pasar sepatu olahraga di Indonesia. Indonesia memiliki merek sepatu lokal yang mampu bersaing dengan merek sepatu dari luar dan dengan adanya merek-merek luar dan lokal yang meramaikan pasar sepatu olahraga di Indonesia membuat persaingan pada bisnis ini semakin ketat.

Terdapat beberapa merek sepatu olahraga di Indonesia yang sering dibeli dan digunakan oleh masyarakat Indonesia, seperti Adidas, Nike dan Reebok juga 
terdapat merek sepatu dari dalam negeri yaitu Eagle yang cukup dikenal di pasar Indonesia. Perusahaan yang memiliki posisi kuat dalam bisnis ini adalah Adidas. Perusahaan Adidas memproduksi berbagai macam peralatan olahraga seperti baju, celana, sepatu, dan barang lainnya. Adidas adalah produsen peralatan olahraga yang memiliki skala global termasuk di Indonesia dan hingga saat ini masih menjadi salah satu perusahaan yang menjual produknya di Indonesia. Produk yang lebih dikenal oleh masyarakat Indonesia dari perusahaan Adidas adalah sepatu olahraga. Terdapat beragam model, warna dan jenis pada sepatu merek Adidas dengan ciri khas tiga garis yang dimiliki oleh Adidas. Hal tersebut menunjukkan masih tingginya minat konsumen untuk membeli produk sepatu merek Adidas. Menurut (Madahi et al., 2012), minat konsumen adalah keinginan yang timbul dari proses pengaktivan ingatan sebagai sebuah rencana yang tersimpan. Minat merupakan proposisi yang menghubungkan diri sendiri dan perilaku di masa yang akan datang (Paul dan Oslon, 2013:149).

Hasil survey yang diperoleh dari top brand award di Indonesia pada tahun 2017 menunjukkan bahwa banyaknya pesaing produk sepatu olahraga di Indonesia. Terdapat dua merek sepatu yang menduduki peringkat teratas. Peringkat pertama adalah merek Adidas dengan perolehan top brand index sebesar 38.2, sedangkan pada peringkat kedua adalah merek Nike dengan perolehan top brand index sebesar 32,2. Berdasarkan hal tersebut, perusahaan Adidas tentunya harus menggunakan strategi yang jitu, serta terus mengembangkan inovasi terhadap produknya dengan tetap memperhatikan 
kualitas produknya. Produk harus memiliki tingkat kualitas tertentu karena produk dibuat untuk memenuhi selera konsumen atau memuaskan pemakaianya.

Sebelum konsumen menggunakan suatu produk yang akan dibelinya, konsumen cenderung mengandalkan informasi dari orang lain yang sudah terlebih dahulu membeli produk tersebut. Keputusan konsumen dalam memutuskan untuk memilih suatu merek atau membeli suatu produk tidak lepas dari perilaku konsumen yang dipengaruhi banyak faktor (Widyastuti dan Alwani, 2018). Jika hal tersebut tidak sesuai untuk mereka, maka mereka akan menolak produk tersebut Brand image merupakan gambaran atau kesan yang ditimbulkan oleh suatu merek dalam benak pelanggan. (Khraim, 2011). Brand image menurut (Roslina, 2010) merupakan petunjuk yang akan digunakan oleh konsumen untuk mengevaluasi produk ketika konsumen tidak memiliki pengetahuan yang cukup tentang suatu produk. Ketika seorang konsumen memperoleh kepuasan pada pembelian sebelumnya, dari situ terjadi pnguatan pemikiran positif konsumen terhadap produk atau jasa (Halim et al., 2014). Brand image yang baik akan mempermudah konsumen dalam mengenali suatu produk serta menciptakan persepsi yang baik akan kualitas produk dan memungkinkan konsumen untuk melakukan niat pembelian bahkan pembelian ulang terhadap produk tersebut. Chen et al. (2013) menemukan bahwa pemasaran dapat memberikan strategi merek yang tepat untuk konsumen sesuai dengan segmen yang berbeda untuk memperkuat asosiasi merek secara positif. Menurut Ranto (2013), membangun merek sudah menjadi keharusan bagi perusahaan untuk dapat bersaing dengan perusahaan lain. 
Penelitian ini dilakukan yang didasarkan pada beberapa temuan dari penelitian sebelumnya tentang pengaruh brand image, kualitas produk dan niat beli ulang dengan hasil yang berbeda-beda. Hasil penelitian dari Ramadhan dan Sentosa (2017) menyatakan bahwa kualitas produk tidak berpengaruh signifikan terhadap niat beli ulang. Hasil ini bertolak belakang dengan penelitian Aryadhe dan Rastini (2016) yang menyatakan bahwa kualitas produk dan brand image memiliki pengaruh positif terhadap niat beli ulang. Hal ini sejalan dengan hasil penelitian Yunus (2014), kualitas produk berpengaruh signifikan terhadap niat beli ulang.

Kotler dan Amstrong (2012:283) mendefinisikan kualitas produk adalah kemampuan sebuah produk dalam memperagakan fungsinya, hal ini termasuk keseluruhan durabilitas, reliabilitas, ketepatan, kemudahan pengoperasian, dan reparasi produk, juga atribut produk lainnya. Konsumen menginginkan produk yang dibelinya sesuai dengan keinginannya atau produk tersebut berkualitas. Semakin tinggi kualitas produk, maka semakin tinggi keputusan konsumen untuk melakukan pembelian (Idris, 2013). Ehsani (2015), menyatakan bahwa kualitas produk adalah persepsi pelanggan terhadap keseluruhan kualitas atau keunggulan produk atau layanan, sehubungan dengan tujuannya, relatif terhadap alternatif.

Menurut penelitian yang dilakukan oleh Amryyanti (2013); Tjahjaningsih dan Yuliani (2009); serta Saidani dkk. (2012) kualitas produk memiliki beberapa indikator diantaranya : 1) Performance (kinerja), yaitu berhubungan dengan karakteristik operasi dasar dari sebuah produk. Melihat bagaimana kinerja dari produk sepatu merek Adidas yang dihubungkan dengan kebutuhan dari 
konsumen. 2) Durability (daya tahan), berapa lama umur produk terebut dapat bertahan sebelum produk sepatu merek Adidas tersebut harus diganti karena sudah tidak dapat lagi memberikan fungsinya. 3) Conformance to specifications (kesesuaian dengan spesifikasi). Sejauh mana produk tersebut dapat memenuhi spesifikasi atau dalam produk sepatu merek Adidas tersebut tidak ditemukan suatu kecacatan atau kerusakan pada produk tersebut. 4). Features (tampilan), karakteristik produk yang dirancang untuk menyempurnakan fungsi produk atau ketertarikan konsumen terhadap produk sepatu merek Adidas. 5)Aesthetics (estetika), berhubungan dengan bagaimana penampilan produk sepatu merek adidas itu sendiri sehingga dapat menarik perhatian dari konsumen. 6) Perceived quality (kesan kualitas), bagaimana hasil dari penggunaan pengukuran yang dilakukan secara tidak langsung karena dapat kemungkinan bahwa konsumen tidak mengerti atau kekurangan informasi mengenai produk yang bersangkutan

Kotler dan Keller (2012: 274) citra merek (brand image) merupakan persepsi masyarakat terhadap perusahaan atau produknya. Image atau citra sendiri adalah suatu gambaran, penyerupaan kesan utama atau garis besar bahkan bayangan yang dimiliki oleh seseorang tentang suatu. Citra merek adalah persepsi dan keyakinan terhadap sekumpulan asosiasi suatu merek yang terjadi dibenak konsumen (Sari, 2013). Menurut Adil (2012) fungsi utama citra merek adalah untuk menjawab pertanyaan tentang bagaimana konsumen memilih diantara merek alternatif setelah melakukan pengambilan informasi. Menurut Evelina dkk. (2013), citra merek (brand image) merupakan representasi dari keseluruhan persepsi terhadap merek dan dibentuk dari informasi dan pengalaman masa lalu 
terhadap merek itu. Oleh karena itu citra atau image dapat dipertahankan. Ini mengandung interpretasi target pasar terhadap atribut produk, manfaat, situasi penggunaan, pengguna, dan karakteristik pembuatan atau pasar. (Rizan et al., 2012) mengemukakan bahwa brand image adalah anggapan tentang merek yang direfleksikan konsumen yang berpegang pada ingatan konsumen.

Menurut (Shahrinaz et al., 2016) memposisikan merek dan menciptakan kesadaran merek dari produk yang dimaksudkan melibatkan banyak perencanaan dan pelaksanaan kampanye iklan yang akan membantu pelanggan dalam mengenali merek dan menciptakan loyalitas merek. Bruhn dkk. (2012) membagi konsepnya mengenai citra merek menjadi dua bagian, yakni citra merek fungsional dan hedonik. Citra merek fungsional berkaitan dengan aspek kinerja atau penggunaan merek, sedangkan citra merek hedonik berkaitan dengan emosi konsumen terhadap merek.

Menurut penelitian yang dilakukan oleh Dharma dan Sukaatmadja (2015) indikator brand image adalah : 1) Atribut produk (product attributes) yang merupakan hal hal yang berkaitan merek tersebut sendiri diantaranya kemasan, isi, produk, harga, rasa, dan warna. 2) Manfaat (consumer benefits) yang merupakan kegunaan produk dari merek tersebut. 3) Kepribadian merek (brand personality) yang merupakan asosiasi kepribadian sebuah merek apabila merek tersebut seorang manusia. 4) Sikap merek (brand attitude) yang merupakan evaluasi keseluruhan atas semua merek, sejauh mana konsumen percaya bahwa produk atau jasa tersebut memiliki keuntungan dan atribut tertentu, dan penilaian 
evaluatif atas kepercayaan suatu produk jika memiliki keuntungan dan atribut yang dimiliki produk tersebut.

Menurut (Shahrinaz et al., 2016) memposisikan merek dan menciptakan kesadaran merek dari produk yang dimaksudkan melibatkan banyak perencanaan dan pelaksanaan kampanye iklan yang akan membantu pelanggan dalam mengenali merek dan menciptakan loyalitas merek. Bruhn dkk. (2012) membagi konsepnya mengenai citra merek menjadi dua bagian, yakni citra merek fungsional dan hedonik. Citra merek fungsional berkaitan dengan aspek kinerja atau penggunaan merek, sedangkan citra merek hedonik berkaitan dengan emosi konsumen terhadap merek.

Kotler (2012: 190) menyatakan keputusan pembelian adalah tahap dalam proses pengambilan keputusan dimana konsumen benar-benar membeli. Kotler dan Keller (2012: 193) menyatakan terdapat enam tahap keputusan pembelian yang dilakukan oleh konsumen yaitu: 1) Pemilihan produk. Konsumen mengambil keputusan untuk membeli sebuah produk atau menggunakan uangnya untuk tujuan yang lain. Dalam hal ini perusahaan harus memusatkan perhatiannya kepada orang-orang yang berminat membeli produknya. 2) Pemilihan merek. Konsumen harus mengambil keputusan tentang merek mana yang akan dibeli. Setiap merek mempunyai perbedaan tersendiri. Dalam hal ini perusahaan harus mengetahui bagaimana konsumen memilih sebuah merek. 3) Pemilihan saluran pembelian. Konsumen harus mengambil keputusan tentang penyalur mana yang akan dikunjungi. Setiap konsumen berbeda-beda dalam hal menentukan penyalur biasanya dikarenakan faktor lokasi yang dekat, harga yang murah, persediaan 
barang yang lengkap, kenyamanan belanja, keluasan tempat dan sebagainya. 4) Jumlah pembelian. Konsumen dapat mengambil keputusan seberapa banyak produk yang akan dibelinya. Dalam hal ini perusahaan harus mempersiapkan banyaknya produk sesuai dengan kebutuhan konsumen. 5) Waktu pembelian Keputusan konsumen dalam waktu pembelian bisa berbedabeda, misalnya: ada yang membeli setiap hari, seminggu sekali, dua minggu sekali, bahkan satu bulan sekali tergantung kebutuhannya.

Menurut Hasan (2013:173) minat beli merupakan kecenderungan konsumen untuk membeli suatu merek atau mengambil tindakan yang berhubungan dengan pembelian yang diukur dengan tingkat kemungkinan konsumen melakukan pembelian untuk memprediksi perilaku konsumen di waktu yang akan datang. Niat beli ulang merupakan bagian dari perilaku pembelian konsumen di mana kesesuaian antara performa dari produk atau jasa yang ditawarkan perusahaan menghasilkan minat konsumen untuk mengkonsumsinya lagi di masa yang akan datang (Wijaya, 2015).

Ain dan Ratnasari (2015) menyatakan bahwa niat beli ulang merupakan tindakan pasca pembelian yang disebabkan oleh adanya kepuasan yang dirasakan konsumen atas produk yang telah dibeli atau dikonsumsi sebelumnya. Niat pembelian ulang merupakan suatu komitmen konsumen yang terbentuk setelah konsumen melakukan pembelian suatu produk atau jasa.

Sunyoto (2013: 85) menyatakan keputusan pembelian yang dilakukan oleh konsumen memiliki struktur. Struktur keputusan pembelian antara lain: 1) Keputusan tentang jenis produk. Konsumen dapat mengambil keputusan untuk 
membeli sebuah produk. Konsumen memilki minat untuk membeli produk dan mempertimbangkan alternatif produk lain. 2) Keputusan tentang bentuk produk. Konsumen akan mempertimbangkan ukuran, mutu, corak dan sebagainya. Perusahaan harus memperhatikan kesukaan konsumen terhadap produk yang bersangkutan agar dapat memaksimumkan daya merek produk. 3) Keputusan tentang penjual. Konsumen akan memutuskan dimana produk tersebut akan dibeli sehingga perusahaan harus memperhatikan bagaimana konsumen memilih penjual tertentu. 4) Keputusan tentang jumlah produk. Konsumen dapat mengambil keputusan tentang berapa banyak produk yang harus dibeli pada suatu waktu. Perusahaan perlu mempersiapkan jumlah produk sesuai dengan keinginan konsumen yang berbeda. 5) Keputusan tentang waktu pembelian. Konsumen dapat mengambil keputusan tentang kapan produk harus dibeli sehingga perusahaan harus mengetahui faktor yang mempengaruhi keputusan konsumsi dalam penentuan waktu pembelian.

Konsumen akan menilai suatu produk berkualitas tinggi apabila memiliki elemen-elemen ini dan tentunya ini dapat menunjukkan kemampuannya memenuhi kebutuhan konsumen dan sesuai dengan ekspektasi mereka terhadap produk. Kualitas suatu produk dapat mempengaruhi konsumen dalam pembentukan citra sebuah merek. Apabila kualitas produk sebuah merek yang dijual tinggi, maka konsumen akan mengasosiasikan kualitas produk yang tinggi pada merek tersebut, yang berarti citra merek tersebut adalah baik. Kualitas produk menjadi hal yang sangat penting karena itu menyangkut kepercayaan konsumen terhadap produk dan perusahaan itu sendiri karena kualitas yang baik 
akan melahirkan citra yang positif dibenak konsumen sehingga konsumen menjadi percaya terhadap produk tersebut (Anis dkk, 2015). Apabila kualitas produk baik di mata konsumen, maka secara otomatis terbentuk citra merek yang positif di mata konsumen. Berdasarkan hasil penelitian terdahulu mengemukakan bahwa kualitas produk berpengaruh positif signifikan terhadap citra merek (Noerchoidah, 2013; Yusmawan et al., 2014). Laura dan Siska (2017), menyatakan bahwa kualitas produk mempengaruhi secara positif signifikan terhadap citra merek. H1: Kualitas produk berpengaruh positif dan signifikan terhadap brand image.

Menurut Kotler dan Amstrong (2014:347) kualitas produk adalah kemampuan suatu produk untuk melakukan fungsi-fungsinya, kemampuan ini meliputi daya tahan, kehandalan, ketelitian yang dihasilkan, kemudahan dioperasikan dan diperbaiki, dan atribut lain yang berharga pada produk secara keseluruhan.

Dalam hasil penelitian Zulfadly (2013) dalam penelitiannya yang berjudul "Pengaruh Kualitas Produk, Harga Dan Brand Image Terhadap Keputusan Pembelian Ulang Produk Yakult Di Kota Padang" menunjukkan hasil bahwa kualitas produk berpengaruh signifikan terhadap keputusan pembelian ulang. Penelitian lain juga dilakukan Saidani dan Arifin (2012) yang menunjukkan bahwa kualitas produk berpengaruh positif dan signifikan terhadap minat beli ulang. Berdasarkan hasil penelitian bahwa bahwa kualitas produk memiliki pengaruh yang paling besar, kualitas produk semakin terjaga dan ditingkatkan maka akan terciptanya niat beli ulang yang tinggi. H2: Kualitas produk berpengaruh positif dan signifikan terhadap niat beli ulang. 
Tariq et al. (2013) menyatakan bahwa citra merek adalah aspek yang sangat penting terhadap niat pembelian. Ini membantu konsumen untuk memutuskan apakah merek yang dipilih adalah pilihan yang lebih baik bagi mereka dan mereka dipaksa untuk membuat niat pembelian beberapa kali. Sebuah citra yang baik membantu untuk menciptakan hubungan jangka panjang antara produk dan pengguna akhir. Hal ini terjadi ketika konsumen merasa puas terhadap produk/jasa yang di terima dari suatu perusahaan penyedia barang/jasa tersebut maka sangat besar kemungkinan bagi konsumen untuk melakukan pembelian ulang. Ain dan Ratnasari (2015), menyatakan bahwa citra merek yang kuat dan positif akan meningkatkan niat beli ulang konsumen, sebaliknya jika citra merek kurang baik, maka niat beli ulang akan menurun. Thakur and Singh (2012) menyatakan adanya hubungan positif antara citra merek dengan niat beli ulang konsumen atas suatu merek atau produk. Citra merek dibentuk melalui berbagai atribut dengan tujuan salah satunya yaitu untuk membentuk sikap yang positif terhadap suatu merek serta membangkitkan niat untuk membeli merek tersebut, dengan kata lain, citra merek berpengaruh secara signifikan terhadap niat beli ulang. H3: Brand image berpengaruh positif dan signifikan terhadap niat beli ulang.

Berdasarkan penelitian yang dilakukan oleh Anggitan (2013) menunjukan bahwa kualitas produk memiliki pengaruh positif langsung dengan niat beli ulang baik secara tidak langsung melalui brand image. Hal tersebut serupa dengan hasil uji penelitian yang dilakukakan oleh Andriadi dan Untarini (2013) bahwa citra merek pada salah satu dimensinya memiliki pengaruh yang signifikan yang dapat membentuk niat beli ulang konnsumen. Aryadhe dan Rasini (2016) dalam hasil 
penelitiannya menemukan bahwa kualitas produk melalui brand image berpengaruh secara positif dan signifikan terhadap niat beli ulang. H4: Brand image berpengaruh positif sebagai mediasi kualitas produk terhadap niat beli ulang.

\section{METODE PENELITIAN}

Lokasi penelitian ini dilakukan pada konsumen yang sudah pernah membeli dan memakai produk sepatu merek Adidas di Kota Denpasar. Dipilihnya Kota Denpasar sebagai lokasi penelitian karena pertimbangan bahwa lokasi ini merupakan pusat kota di Bali dengan pertumbuhan sektor ekonomi yang cepat. Selain itu jumlah penduduk yang padat dan populasi yang cukup tinggi yang mencerminkan gaya hidup masyarakat Bali yang update akan kebutuhankebutuhan produk-produk baru, terutama produk fashion seperti sepatu yang digunakan sehari-hari. Secara teknis, Kota Denpasar memenuhi katagori yang dinilai efektif dan efisien dalam menyelenggarakan penelitian yang relevan, mengingat dari segi pendapatan penduduk yang berdomisili dan bekerja di Denpasar memiliki rata-rata pendapatan yang lebih tinggi dibandingkan dengan wilayah lainnya. Penduduk Kota Denpasar memiliki kemampuan untuk membeli produk dengan harga menengah keatas atau dapat dikatakan mewah dengan kualitas yang lebih baik seperti produk sepatu merek Adidas.

Objek di dalam penelitian ini adalah pengaruh kualitas produk (X) terhadap brand image $\left(\mathrm{Y}_{1}\right)$, pengaruh kualitas produk $(\mathrm{X})$ terhadap niat beli ulang $\left(\mathrm{Y}_{2}\right)$, pengaruh brand image $\left(\mathrm{Y}_{1}\right)$ terhadap niat beli ulang $\left(\mathrm{Y}_{2}\right)$, dan pengaruh brand image $\left(\mathrm{Y}_{1}\right)$ memediasi kualitas produk $(\mathrm{X})$ dan niat beli ulang $(\mathrm{Y})$. 
Tabel 1.

Konstruk dan Indikator

\begin{tabular}{|c|c|c|c|c|}
\hline No & $\begin{array}{l}\text { Klasifikasi } \\
\text { Konstruk }\end{array}$ & Konstruk & Indikator & Sumber \\
\hline 1 & $\begin{array}{l}\text { Variabel } \\
\text { Eksogen } \\
\text { (X) }\end{array}$ & $\begin{array}{l}\text { Kualitas } \\
\text { Produk }\end{array}$ & $\begin{array}{l}\text { 1. Kinerja sepatu merek Adidas dapat } \\
\text { memenuhi kebutuhan merek dengan baik. } \\
\text { 2. Pada produk sepatu merek Adidas tidak } \\
\text { ditemukan kecacatan. } \\
\text { 3. Produk sepatu merek Adidas dapat } \\
\text { digunakan dengan mudah. } \\
\text { 4. Produk sepatu merek Adidas memiliki } \\
\text { tampilan yang menarik. } \\
\text { 5. Produk sepatu merek Adidas memiliki } \\
\text { estetika dengan perpaduan warna yang } \\
\text { cocok } \\
\text { 6. Secara keseluruhan produk sepatu merek } \\
\text { Adidas sangat baik untuk digunakan. }\end{array}$ & $\begin{array}{l}\text { Amryyanti } \\
\text { (2013); } \\
\text { Tjahjaningsih } \\
\text { danYuliani } \\
\text { (2009);serta } \\
\text { Saidani,dkk } \\
\text { (2012) }\end{array}$ \\
\hline 2. & $\begin{array}{l}\text { Variabel } \\
\text { Mediasi }\left(\mathrm{Y}_{1}\right)\end{array}$ & $\begin{array}{l}\text { Brand } \\
\text { Image }\end{array}$ & $\begin{array}{l}\text { 1. Produk sepatu merek Adidas memiliki } \\
\text { atribut produk yang baik. } \\
\text { 2. Produk sepatu merek Adidas memberikan } \\
\text { manfaat yang baik saat digunakan. } \\
\text { 3. Produk sepatu merek Adidas dapat } \\
\text { meningkatkan rasa percaya diri } \\
\text { 4. Percaya produk sepatu merek Adidas } \\
\text { memberikan kualitas terbaik bagi } \\
\text { pelanggannya. }\end{array}$ & $\begin{array}{l}\text { Dharma dan } \\
\text { Sukaatmadja } \\
\text { (2015) }\end{array}$ \\
\hline 3. & $\begin{array}{l}\text { Variabel } \\
\text { Endogen } \\
\left(\mathrm{Y}_{2}\right)\end{array}$ & $\begin{array}{l}\text { Niat Beli } \\
\text { Ulang }\end{array}$ & $\begin{array}{l}\text { 1. Pelanggan akan membeli kembali produk } \\
\text { sepatu merek Adidas } \\
\text { 2. Pelanggan akan memilih produk sepatu } \\
\text { merek Adidas pada pembelian berikutnya. } \\
\text { 3. Pelanggan akan merekomendasikan } \\
\text { produk sepatu merek Adidas kepada rekan } \\
\text { dan teman. } \\
\text { 4. Pelanggan menjaga niat untuk membeli } \\
\text { ulang produk sepatu merek Adidas di } \\
\text { masa yang akan datang. } \\
\text { 5. Pelanggan selalu mencari tahu } \\
\text { perkembangan terkini tentang produk } \\
\text { sepatu merek Adidas. }\end{array}$ & $\begin{array}{l}\text { Chaudhuri and } \\
\text { Ligas (2009) }\end{array}$ \\
\hline
\end{tabular}

Sumber: Data diolah, 2018

Populasi dalam penelitian ini adalah para konsumen yang sudah pernah membeli atau memakai produk sepatu merek Adidas di Kota denpasar. Metode penentuan sampel yang digunakan dalam penelitian ini adalah non probability sampling. Tehnik pengambilan sampel ditentukan dengan metode purposive sampling merupakan metode pemilihan sampel berdasarkan pertimbangan tertentu (Sugiyono, 2017:85). Dalam sebuah penelitian untuk memperoleh suatu data yang 
valid maka jumlah sampel responden yang diambil dan ditentukan paling sedikitnya 5-10 kali jumlah indikator (Sugiyono. 2017:130) sehingga jumlah dari sampel responden yang akan diuji di dapat dari hasil perhitungan sebagai berikut:

$$
\begin{aligned}
\text { Jumlah Responden } & =15 \text { indikator } \times 8 \\
& =120 \text { responden }
\end{aligned}
$$

Metode pengumpulan data yang digunakan dalam penelitian ini adalah survey atau angket. Instrumen penelitiannya adalah kuesioner. Kuesioner merupakan metode pengumpulan data yang dilakukan dengan cara memberikan seperangkat pertanyaan tertulis pada responden untuk dijawabnya (Sugiyono, 2017:142). Tipe pertanyaan pada kuesioner adalah pertanyaan tertutup, dimana responden diminta untuk membuat pilihan dari serangkaian alternatif pilihan jawaban yang terdapat di kuesioner. Alternatif jawaban yang terdapat dalam kuesioner merupakan pengembangan dari setiap item dalam variabel penelitian. Responden harus memberikan pendapatnya dengan cara memberi tanda tertentu pada jawaban yang dipilih. Pertanyaan yang diberikan menyangkut pada indikator masing-masing variabel yang digunakan dalam penelitian ini.

Penelitian ini memakai teknik analisis jalur atau biasa disebut path analysis. Analisis jalur atau path analysis merupakan perluasan analisis statistik yang dikembangkan dari regresi berganda. Menurut Riduwan dan Kuncoro (2011:2) model path analysis digunakan untuk menganalisis pola hubungan antar variabel dengan tujuan untuk mengetahui pengaruh langsung maupun tidak langsung seperangkat variabel eksogen (kualitas produk) terhadap variabel endogen (niat beli ulang). Dalam analisis ini subjek utamanya adalah variabel-variabel yang 
memiliki korelasi dan model hubungan antar variabel tersebut ditentukan sebelumnya oleh peneliti. Dasar perhitungan koefisien jalur adalah analisis korelasi dan regresi dalam perhitungan menggunakan software dengan program SPSS 13.00 for windows.

Dalam pengujian hipotesis mediasi dapat ditempuh dengan prosedur yang telah dikembangkan oleh (Sobel, 1982) dan dikenal dengan istilah uji sobel atau biasa disebut dengan sobel test. Uji sobel dipakai untuk menguji seberapa kekuatan pengaruh tidak langsung antara variabel kualitas produk $(\mathrm{X})$ ke variabel niat beli ulang produk Adidas. $\left(\mathrm{Y}_{2}\right)$ melalui variabel brand image $\left(\mathrm{Y}_{1}\right)$. Pengaruh tidak langsung variabel kualitas produk (X) ke variabel niat beli ulang produk Adidas $\left(\mathrm{Y}_{2}\right)$ melalui variabel brand image $\left(\mathrm{Y}_{1}\right)$ dihitung, dengan cara mengalikan antara koefisien jalur $(\mathrm{X})$ terhadap $\left(\mathrm{Y}_{1}\right)(\mathrm{a})$, dengan koefisien jalur $\mathrm{Y}_{1}$ terhadap $\mathrm{Y}_{2}$ (b) atau ab. Standard error dari koefisien a dan b nantinya ditulis dengan huruf atau simbol $\mathrm{S}_{\mathrm{a}}$ dan $\mathrm{Sb}$ dan besarnya standard error tidak langsung ( indirect effect) $\mathrm{S}_{\mathrm{a}} \mathrm{b}$.

\section{HASIL PENELITIAN DAN PEMBAHASAN}

Menurut pengelompokan usia, mayoritas responden berusia 20 - 25 Tahun sebanyak 62,5\%, lalu responden berusia di atas 25 tahun sebanyak 16,7\% dan responden berusia di bawah 20 tahun sebanyak 20,8\%. Dilihat dari jenis kelamin responden, wanita mendominasi yaitu sebanyak 52,5\% dan pria sebanyak 47,5\%.

Pengujian data dalam penelitian ini menggunakan teknik analisis jalur (Path Analysis), di mana analisis jalur adalah perluasan dari analisis regresi linear 
berganda untuk menguji hubungan kausalitas antara 2 atau lebih variabel. Tahapan melakukan teknik analisis jalur yaitu:

Persamaan Sub-struktural 1

$Y_{1}=\beta_{1} X+e 1$

Persamaan Sub-struktural 2

$Y_{2}=\beta_{2} X+\beta_{3} Y_{1}+e 2$

Perhitungan koefisien path dilakukan dengan analisis regresi melalui software SPSS 18.0 for Windows, diperoleh hasil yang ditunjukan pada Tabel 2. dan Tabel 3.

Tabel 2.

Hasil Analisis Jalur Persamaan Regresi 1

\begin{tabular}{lccccc}
\hline \multicolumn{1}{c}{ Model } & \multicolumn{2}{c}{$\begin{array}{c}\text { Unstandardized } \\
\text { Coefficients }\end{array}$} & $\begin{array}{c}\text { Standardized } \\
\text { Coefficients } \\
\text { Beta }\end{array}$ & t hitung & Sig. \\
& $\boldsymbol{B}$ & Std.Error & Beta & \\
\hline 1 (Constant) & 4,363 & 1,085 & & 4,020 & 0,000 \\
Kualitas Produk & 0,488 & 0,042 & 0,734 & 11,734 & 0,000 \\
R1 Square & & & & & 0,538 \\
F Statistik & & & & 137,683 \\
Signifikansi & & & & 0,000 \\
\hline
\end{tabular}

Sumber: Data diolah, 2018

Berdasarkan hasil analisis jalur substruktur 1 seperti yang disajikan pada

Tabel 2., maka persamaan strukturalnya adalah sebagai berikut :

$$
\begin{aligned}
& \mathrm{Y}_{1}=\beta_{1} \mathrm{X}+\varepsilon_{1} \\
& \mathrm{Y}_{1}=0,734 \mathrm{X}+\varepsilon_{1}
\end{aligned}
$$

Nilai $\beta_{1}$ adalah sebesar 0,734 memiliki arti bahwa Kualitas Produk berpengaruh positif terhadap Brand Image, dengan kata lain jika Kualitas Produk meningkat maka akan mengakibatkan peningkatan Brand Image sepatu merek Adidas.

Tabel 3. 
Hasil Analisis Jalur Persamaan Regresi 2

\begin{tabular}{lccccc}
\hline \multicolumn{1}{c}{ Model } & \multicolumn{2}{c}{$\begin{array}{c}\text { Unstandardized } \\
\text { Coefficients }\end{array}$} & $\begin{array}{c}\text { Standardized } \\
\text { Coefficients } \\
\text { Beta }\end{array}$ & $\mathbf{t}_{\text {hitung }}$ & Sig. \\
& $\boldsymbol{B}$ & Std.Error & & \\
\hline 1 (Constant) & 0,559 & 1,952 & & 0,286 & 0,775 \\
Kualitas Produk & 0,240 & 0,103 & 0,229 & 2,319 & 0,022 \\
Brand Image & 0,794 & 0,155 & 0,504 & 5,111 & 0,000 \\
& & & & & \\
R1 Square & & & & & 0,475 \\
F Statistik & & & & & 52,983 \\
Signifikansi & & & & & \\
\hline
\end{tabular}

Sumber: Data diolah, 2018

Berdasarkan hasil analisis jalur substruktur 2 seperti yang disajikan pada

Tabel 3. maka persamaan strukturalnya adalah sebagai berikut :

$$
\begin{aligned}
& \mathrm{Y}_{2}=\beta_{2} \mathrm{X}+\beta_{3} \mathrm{Y}_{1}+\varepsilon_{2} \ldots \ldots \ldots \\
& \mathrm{Y}_{2}=0,229 \mathrm{X}+0,504 \mathrm{Y}_{1}+\varepsilon_{2}
\end{aligned}
$$

Berdasarkan persamaan tersebut maka dapat disimpulkan bahwa nilai $\beta_{2}$ adalah sebesar 0,229 memiliki arti bahwa kualitas produk berpengaruh positif terhadap niat beli ulang, dengan kata lain jika faktor kualitas produk meningkat maka akan mengakibatkan peningkatan pada niat beli ulang sepatu merek Adidas di Kota Denpasar.

Nilai $\beta_{3}$ adalah sebesar 0,504 memiliki arti bahwa brand image berpengaruh positif terhadap niat beli ulang, dengan kata lain jika brand image meningkat maka akan terjadi peningkatan niat beli ulang pada sepatu merek Adidas di Kota Denpasar.

Berdasarkan model substruktur 1 dan substruktur 2, maka dapat disusun model diagram jalur akhir. Sebelum menyusun model diagram jalur akhir, terlebih dahulu dihitung nilai standar eror sebagai berikut:

$$
\mathrm{Pe}_{\mathrm{i}}=\sqrt{1-\mathrm{R}_{\mathrm{i}}^{2}}
$$




$$
\begin{aligned}
& \mathrm{Pe}_{1}=\sqrt{1-R_{1}^{2}}=\sqrt{1-0,538}=0,679 \\
& \mathrm{Pe}_{2}=\sqrt{1-R_{2}^{2}}=\sqrt{1-0,475}=0,724
\end{aligned}
$$

Berdasarkan perhitungan pengaruh error $\left(\mathrm{Pe}_{1}\right)$, didapatkan hasil pengaruh error $\left(\mathrm{Pe}_{1}\right)$ sebesar 0,679 dan pengaruh error $\left(\mathrm{Pe}_{2}\right)$ sebesar 0,724. Hasil koefisien determinasi total adalah sebagai berikut:

$$
\begin{aligned}
\mathrm{R}_{\mathrm{m}}^{2} & =1-\left(\mathrm{Pe}_{1}\right)^{2}\left(\mathrm{Pe}_{2}\right)^{2} \\
& =1-(0,679)^{2}(0,724)^{2} \\
& =1-(0,461)(0,524) \\
& =1-0,241=0,759
\end{aligned}
$$

Nilai determinasi total sebesar 0,759 mempunyai arti bahwa sebesar 75,9\% variasi niat beli ulang dipengaruhi oleh variasi kualitas produk dan brand image, sedangkan sisanya sebesar $24,1 \%$ dijelaskan oleh faktor lain yang tidak dimasukkan ke dalam model.

Besarnya pengaruh langsung dan pengaruh tidak langsung serta pengaruh

\begin{tabular}{|c|c|c|c|c|c|}
\hline $\begin{array}{l}\text { Pengaruh } \\
\text { Variabel }\end{array}$ & $\begin{array}{l}\text { Pengaruh } \\
\text { Langsung }\end{array}$ & $\begin{array}{l}\text { Pengaruh Tidak } \\
\text { Brand Image } \\
\left(\mathrm{Y}_{1}\right)(\boldsymbol{\beta} 1 \times \mathbf{\beta} 3)\end{array}$ & Langsung & Melalui & Pengaruh Total \\
\hline $\mathrm{X}_{1} \rightarrow \mathrm{Y}_{1}$ & 0,734 & - & & & 0,734 \\
\hline $\mathrm{X}_{1} \rightarrow \mathrm{Y}_{2}$ & 0,229 & 0,369 & & & 0,598 \\
\hline
\end{tabular}
total antar variabel. Perhitungan pengaruh antar variabel terdapat dalam Tabel 4 sebagai berikut.

Tabel 4.

Pengaruh Langsung dan Pengaruh Tidak Langsung serta Pengaruh Total Kualitas Produk (X), Brand Image (Y1), dan Niat Beli Ulang ( $\left.\mathrm{Y}_{2}\right)$ 


\begin{tabular}{cccc}
$\mathrm{Y}_{1} \rightarrow \mathrm{Y}_{2}$ & 0,504 & - & 0,504 \\
\hline Sumber: & Data diolah, 2018 &
\end{tabular}

Uji sobel dihitung dengan rumus dibawah ini:

$Z=\frac{a b}{\sqrt{b^{2} s_{a}^{2}+a^{2} s_{b}^{2}+s_{a}^{2} s_{b}^{2}}} \ldots$

$\operatorname{Sig}=(1-\operatorname{NORMDIST}(Z))+2))$

Keterangan:

$$
\begin{gathered}
\mathrm{a} \quad=0,734 \\
\mathrm{~S}_{\mathrm{a}}=0,042 \\
\mathrm{~b}=0,504 \\
\mathrm{Sb}=0,155 \\
Z=\frac{0,734,0,504}{\sqrt{0,504^{2} 0,734^{2}+0,734^{2} 0,155^{2}+0,042^{2} 0,155^{2}}} \\
Z=\frac{0,3699}{\sqrt{0,0004+0,0129+0,0000}} \\
Z=\frac{0,3699}{0,1159}=\mathbf{3 , 1 9 1}
\end{gathered}
$$

Tabel 5.

\section{Hasil Uji Sobel}

Sumber: Data diolah, 2018

Hasil dari pengujian variabel mediasi sesuai dengan Tabel 5 yaitu brand image didapatkan $\mathrm{Z}$ hitung sebesar 3,191>1,96 yang berarti $\mathrm{H}_{0}$ ditolak dan $\mathrm{H}_{1}$ diterima yang berarti variabel brand image dinilai secara signifikan memediasi pengaruh variabel kualitas produk pada niat beli ulang pada sepatu merek Adidas di Kota Denpasar.

Pengujian hipotesis pada pengaruh kualitas produk terhadap brand image menunjukkan bahwa kualitas produk secara signifikan berpengaruh positif 
terhadap brand image. Ini berarti semakin baik kualitas produk yang diberikan oleh sepatu merek Adidas maka akan meningkatkan brand image dari sepatu merek Adidas.

Hasil penelitian ini mendukung temuan dari (Noerchoidah, 2013; Yusmawan et al., 2014). Laura dan Siska (2017), menyatakan bahwa kualitas produk mempengaruhi secara positif signifikan terhadap brand image.

Pengujian hipotesis pada pengaruh kualitas produk terhadap niat beli ulang menunjukkan bahwa kualitas produk berpengaruh secara signifikan positif terhadap niat beli ulang. Ini berarti semakin baiknya kualitas produk yang diberikan oleh sepatu merek Adidas, maka akan meningkatkan niat beli ulang konsumen pada sepatu merek Adidas.

Hasil penelitian ini mendukung temuan dari penelitian terdahulu Zulfadly (2013), Saidani dan Arifin (2012) yang menunjukkan bahwa kualitas produk berpengaruh positif dan signifikan terhadap ninat beli ulang.

Pengujian hipotesis pada pengaruh brand image terhadap niat beli ulang menunjukkan bahwa brand image secara signifikan berpengaruh positif terhadap niat beli ulang. Ini berarti semakin baiknya brand image yang diberikan oleh sepatu merek Adidas, maka akan meningkatkan niat beli ulang pada sepatu merek Adidas di Kota Denpasar.

Hasil penelitian ini mendukung temuan dari penelitian terdahulu Ain dan Ratnasari (2015), menyatakan bahwa brand image yang kuat dan positif akan meningkatkan niat beli ulang konsumen, sebaliknya jika brand image kurang baik, maka niat beli ulang akan menurun. Thakur and Singh (2012) menyatakan 
adanya hubungan positif antara citra merek dengan niat beli ulang konsumen atas suatu merek atau produk.

Pengujian hipotesis pada peran brand image dalam memediasi kualitas produk terhadap niat beli ulang menunjukkan bahwa brand image mampu memediasi pengaruh kualitas produk terhadap niat beli ulang. Ini berarti brand image memediasi pengaruh kualitas produk terhadap niat beli ulang secara parsial. Dengan kata lain, brand image memperkuat pengaruh kualitas produk terhadap niat beli ulang.

Hasil penelitian ini mendukung temuan dari Anggitan (2013), Andriadi dan Untarini (2013) serta Aryadhe dan Rasini (2016), yakni kualitas produk melalui brand image berpengaruh secara positif dan signifikan terhadap niat beli ulang.

Implikasi dari penelitian ini mencakup dua hal yaitu, implikasi teoritis dan implikasi praktis yang menekankan pada manfaat nyata dari hasil penelitian ini untuk meningkatkan pelanggan pada produk sepatu merek Adidas. Perusahaan sebaiknya mempertahankan brand image yang baik melalui kualitas produk yang baik sehingga pelanggan mempunyai niat untuk membeli kembali produk sepatu merek Adidas. Beberapa implikasi hasil penelitian ini adalah faktor yang mempengaruhi niat beli ulang dalam peneltian ini adalah kualitas produk dan brand image. Implikasi teoritis yang berkaitan dengan niat beli ulang secara konsisten memperkuat teori sebelumnya bahwa kualitas produk dan brand image memengaruhi pelanggan terhadap timbulnya niat untuk membeli ulang. Selain itu, variabel brand image mampu menjadi pemediasi pengaruh kualitas produk terhadap niat beli ulang. Semakin baik kualitas produk yang dimiliki produk 
sepatu merek Adidas maka akan dapat meningkatkan brand image yang baik dan brand image tersebut memiliki peranan penting dalam mempengaruhi niat pada pembelian ulang terhadap produk sepatu merek Adidas. Hal ini mendukung penelitian yang telah diungkapkan pada hipotesis penelitian, sehingga dapat disimpulkan bahwa penelitian ini mendukung serta memperjelas hubungan antara variabel brand image, kualitas produk, dan niat beli ulang.

Hasil dari penyebaran kuesioner secara spesifik yang ditunjukkan dalam pernyataan responden tentang kualitas produk, brand image dan niat beli ulang bahwa mereka rata-rata setuju pada pernyataan mengenai kualitas produk, brand image dan niat beli ulang, maka dengan begitu dapat disimpulkan bahwa pernyataan tersebut dapat merefleksikan perilaku pembelian konsumen yang berarti bahwa responden memiliki kecenderungan melakukan pembalian ulang terhadap produk spatu merek Adidas di Kota Denpasar.

Patut disadari bahwa terdapat beberapa keterbatasan dari penelitian ini yang diantaranya penelitian ini hanya dilakukan dalam titik waktu tertentu, sedangkan lingkungan setiap saat dapat berubah, yang menyebabkan penelitian ini penting untuk dilakukan kembali pada masa yang mendatang. Kurangnya variabel, di mana masih ada variabel-variabel lain yang dapat mempengaruhi niat beli ulang seperti, citra toko, harga, dan promosi penjualan. Penelitian ini belum spesifik, karena dilakukan pada keseluruhan tipe sepatu merek merek Adidas, sedangkan sepatu merek Adidas memiliki banyak tipe-tipe sepatu merek.

\section{SIMPULAN DAN SARAN}


Simpulan dari penelitian ini serta pembahasan mengenai pengaruh masingmasing vaiabel yang telah dipaparkan, maka dapat ditarik kesimpulan bahwa variabel kualitas produk berpengaruh positif dan signifikan terhadap brand image. Hal tersebut menunjukkan semakin baiknya kualitas produk pada sepatu merek Adidas maka akan meningkatkan brand image dari produk sepatu merek Adidas di Kota Denpasar.

Kualitas produk berpengaruh positif dan signifikan terhadap niat beli ulang. Hal tersebut menunjukkan semakin baiknya kualitas produk pada sepatu merek Adidas maka akan meningkatkan niat beli ulang konsumen produk sepatu merek Adidas di Kota Denpasar.

Brand image berpengaruh positif dan signifikan terhadap niat beli ulang. Hal tersebut menunjukkan semakin baiknya brand image pada sepatu merek Adidas maka akan meningkatkan niat beli ulang konsumen produk sepatu merek Adidas di Kota Denpasar.

Brand image mampu memediasi pengaruh kualitas produk terhadap niat beli ulang. Hal tersebut menunjukkan bahwa brand image memediasi pengaruh kualitas produk terhadap niat beli ulang secara parsial. Dengan kata lain, brand image memperkuat pengaruh kualitas produk ke niat beli ulang.

Adapun saran yang dapat diajukan dalam penelitian ini adalah pihak produsen Adidas diharapkan agar memberi harga khusus untuk para pelanggan dan lebih bisa meningkatkan serta mempertahankan brand image agar Adidas memiliki image yang positif, karena brand image mampu menarik minat konsumen untuk membeli suatu produk. Kualitas ketahanan produk Adidas perlu 
diperbaiki meski produk yang dihasilkan sudah baik, di samping harga bersaing untuk kualitas merek produk sejenis (Nike) agar niat konsumen untuk membeli ulang semakin meningkat.

Bagi peneliti selanjutnya, diharapkan untuk melakukan penelitian secara spesifik pada tipe sepatu merek Adidas. Dalam penelitian ini di masa mendatang juga perlu untuk menggunakan variabel-variabel yang lain seperti citra toko, harga, dan promosi penjualan, sehingga dapat memperkaya informasi yang diperoleh.

\section{REFERENSI}

Adil, M. 2012. The Influence of Brand Image on Sales. Journal of Basic and Applied Scientific Research, 2 (4): 3552-3556.

Ain, N. dan Ratnasari, R.T. 2015. Pengaruh Citra Merek Melalui Sikap Konsumen Terhadap Niat Beli Ulang Pada Produk Busana Muslim Zoya di Surabaya, JESTT, 2 (7): 553-569.

Andriadi, A. dan Untarini, N. 2013. Pengaruh Persepsi Kualitas Layanan dan Citra Merek Telkom Flexi Terhadap Niat Beli Ulang. Jurnal Ilmu Manajemen, 1 (2): 639-649.

Anggitan, A. R. 2013. Analisis Pengaruh Kualitas Produk, Harga dan Promosi Terhadap Loyalitas Pelanggan Dengan Minat Beli Ulang Sebagai Variabel Intervening. Jurnal Manajemen, 7 (9): 1-18.

Anis, L. M., Suharyono dan Sunarti. 2015. Pengaruh Kualitas Produk Terhadap International Brand Image Serta Dampaknya Terhadap Keputusan Pembelian Mahasiswa Pembeli dan Pengguna Laptop Lenovo di Fakultas Ilmu Administrasi Universitas Brawijaya. Jurnal Administrasi Bisnis, 28 (2): 1-6.

Amryyanti, R. 2013. Pengaruh Kualitas Layanan, Produk, dan Kewajaran Harga Terhadap Kepuasan dan Loyalitas Pelanggan Pada LnC skin care Singaraja. E-Jurnal Ekonomi dan Bisnis Universitas Udayana, 2 (1): 22-29.

Aryadhe, P. dan Rastini, N.M . 2016. Kualitas Pelayanan, Kualitas Produk dan Citra Merek Terhadap Niat Beli Ulang di PT. Agung Toyota Denpasar. EJurnal Manajemen Unud, 5 (9): 5696-5721. 
Bruhn, M., Schoenmueller, V. And Schäfer, D.B. 2012. Are Social Media replacing traditional media in terms of brand equity creation. Management Research Review, 35 (9): 770-790.

Chaudhuri, A. and Ligas, M. 2009. Consequences of value in retail markets. Journal of Retailing, 85 (3): 406-419.

Chen, T.Y., Yeh, T.L. and Jheng, W.S. 2013. Factors influencing brand association. African Journal of Business Management, 7 (19): 1914-1926.

Dharma, N.P.S.A dan Sukaatmadja, I.P.G. 2015. Pengaruh Citra Merek, Kesadaran Merek, dan Kualitas Produk terhadap Keputusan Membeli Produk Apple. E -Jurnal Manajemen Unud, 4 (10): 3228-3255

Ehsani, Z. and Ehsani, M.H. 2015. Effect of Quality and Price on Customer Satisfaction and Commitment in Iran Auto Industry. International Journal of Service Sciences, Management and Engineering, 1 (5): 52-56.

Evelina, N., Waloejo, H.D. dan Listyorini, S. 2013. Pengaruh Citra Merek, Kualitas Produk, Harga, dan Promosi Terhadap Keputusan Pembelian Kartu Perdana Telkom Flexi (Studi Kasus pada Konsumen Telkom Flexi di Kecamatan Kota Kudus Kabupaten Kudus). Jurnal Ilmu Administrasi Bisnis, 1 (1): 203-213.

Fouladivanda, F., Pashandi, M.A., Hooman, A. and Khanmohammadi, Z. 2013. The Effect Of Brand Equity On Consumer Buying Behaviour In Term of FMCG In Iran, 4 (9): 1-13.

Halim, B.C., Dharmayanti, D. dan Brahmana, R.K.M.R. 2014. Pengaruh Brand Identity terhadap Timbulnya Brand Preference dan Repurchase Intention pada Merek Toyota. Jurnal Manajemen Pemasaran Petra, 2 (1): 1-11.

Hasan, A. 2013. “Marketing Cetakan Pertama”. Media Pressindo. Yogyakarta.

Idris, H.N.A. 2013. Pengaruh Kualitas Produk Citra Merek, Harga dan Promosi Terhadap Keputusan Pembelian Mobil Jenis Mpv Merek Toyota Kijang Innova di Semarang. Diponegoro Journal Of Management, 2 (3): 1-10.

Kotler, P. (2012). Manajemen Pemasaran Perspektif Asia (Pertama). Yogyakarta: Andi.

Kotler, P. Dan Keller, K.L. 2012. Marketing Management (14th ed.). New Jersey: Pearson Prestice Hall.

Kotler, P. dan Amstrong, G. 2014. Prinsip-prinsip Marketing, Jakarta: Salemba Empat.

Kraim, H.S. 2011. The Influence Brand Loyalty on Cosmetics Buying Behavior of UAE Female Consumers. International Journal of Marketing Studies, 3 (2): 123-133.

Laura, S.N. dan Ringo, S.N.S. 2017. Pengaruh Kualitas Produk dan Kunggulan Bersaing Terhadap Keputusan Pembelian dengan Citra Merek Sebagai 
Variabel Intervening, Journal of Management and Business Review, 14 (2): 258-284. Jakarta: Universitas 17 Agustus 1945 Jakarta.

Madahi, A. and Sukati, I. 2012. "The Effect of External Factors on Purchase Intention amongst Young Generation in Malaysia", International Business Research, 5 (8): 153-159.

Noerchoidah. 2013. Analisis Pengaruh Harga, Kualitas Produk dan Iklan Terhadap Brand Image dan Keputusan Pembelian Sepeda Motor Merek Kawasaki. Jurnal WIG, 3 (1): 48-60.

Paul, J. P. dan Olson, J. 2013. Perilaku Konsumen dan Strategi Pemasaran. Dialih bahasakan oleh Diah Tantri Edisi 9-Buku 1. Jakarta: Salemba Empat.

Puspita, L., Yulianto, E. dan Sunarti. 2016. Pengaruh Kualitas Produk dan Word Of Mouth terhadap Keputusan Pembelian (Survei Kepada Konsumen Charles \& Keith di Tunjungan Plaza Surabaya), Jurnal Administrasi Bisnis (JAB), 34 (1): 79-85.

Ramadhan, A.G. dan Sentosa, S.B. 2017. Analisis Pengaruh Kualitas Produk, Kualitas Pelayanan, dan Citra merek Terhadap Minat beli Ulang Pada Sepatu Nike Running di Semarang Melalui Kepuasan Pelanggan Sebagai Variabel Intervening. Diponogoro Journal Of Management, 6 (1): 1-12

Ranto, D.W.P. 2013. Menciptakan Islamic Branding Sebagai Strategi Menarik Minat Beli Konsumen. Jurnal Bisnis Manajeman Akuntansi, 1 (2): 1-11.

Riduwan dan Kuncoro, E.A. 2011. Cara Menggunakan dan Memakai Path Analysis (analisis jalur). Bandung : Alfabeta.

Rizan, M., Saidani, B. dan Sari, Y. 2012. Pengaruh Brand Image dan Brand Trust Terhadap Brand Loyalty Teh Botol Sosro Survey Konsumen Teh Botol Sosro di Food Court Itc Cempaka Mas, Jakarta Timur. Jurnal Riset Manajemen sains Indonesia (JRMSI), 3 (1): 1-17.

Roslina. 2010. Citra Merek: Dimensi, Proses Pengembangan Serta Pengukuranya. Jurnal Bisnis Dan Manajemen, 6 (3): 333-346.

Saidani, B. dan Arifin, S. 2012. Pengaruh kualitas produk dan kualitas layanan terhadap kepuasan konsumen dan minat beli pada ranch market. JRMSIJurnal Riset Manajemen Sains Indonesia, 3 (1): 1-22.

Sari, A.K. 2013. Pengaruh Citra Merek dan Keluarga Terhadap Keputusan Pembelian Honda Beat. Jurnal Ilmu Manajemen, 1 (1): 285-296.

Shahrinaz, I., Kasuma, J., Yacob, Y., Rahman, D.H.A.A. dan Mahdi, A.F. 2016. Relationship and Impact of E-WOM and Brand Image Towards Purchase Intention of Smartphone. Journal of Scientifc Research And Development, 3 (5): $117-124$.

Sunyoto, D. 2013. Teori, Kuesioner \& Analisis Data. Yogyakarta:Graha Ilmu. 
Tariq, M.I., Nawaz, M.R., Nawaz, M.M and Butt, H.A. 2013. Customer Perceptions about Branding and Purchase Intention: A Study of FMCG in an Emerging Market. Journal of Basic and Applied Scientific Research, 3 (2): $340-347$.

Thakur, S. and Singh, A. P. 2012. Brand Image, Customer Satisfaction and Loyalty Intention: A Study in The Context of Cosmetic Product Among The People of Central India. International Journal of Multidisciplinary Management Studies, 2(5): 22498834.

Tjahjaningsih, E. dan Yuliani, M. 2009. Analisis Kualitas Produk dan Citra Merek dalam Mempengaruhi Keputusan Pembelian dan Dampaknya Terhadap Loyalitas Merek HP Nokia.TEMA, 6 (2): 104-118.

Widyastuti, P. dan Alwani. 2018. Peran Community Advice Sebagai Pemoderasi Dalam Keputusan Pembelian. Jurnal Manajemen dan Pemasaran Jasa. Universitas 17 Agustus 1945 Jakarta, 11 (1): 67-80.

Wijaya, M. dan Jasfar, F. 2014. Pengaruh Rancangan Situs, Harga Kepercayaan, dan Keamanan Terhadap Pembelian Produk Fashion Melalui Online Shopping. Jurnal Manajemen dan Pemasaran Jasa, 7 (2): 31-62.

Wijaya, T. 2015. Pengaruh Service Quality Perception dan Satisfaction Terhadap Repurchase Intention. Modus Jurnal Ekonomi dan Bisnis, 17 (1): 39- 52.

Yunus, A. 2014. Pengaruh Kualitas Produk, Lokasi dan Lingkungan Fisik Terhadap Pembelian Ulang Pada Warung Kopi Harapan J2 di Kota Palu. EJurnal Katalogis. Universitas Tadulako, 2 (7): 1-12.

Yusmawan., S., Kumadji, S. dan Rahardjo. 2014. Journal of The Effect of The Product Quality Mediation And Brand Image on The Influence of Pricing Policy And Service Quality Towards Trust. Journal of Contemporary Research In Business, 5 (9): 236-245.

Zulfadly, E. 2013. Pengaruh Kualitas Produk, Harga dan Brand Image terhadap Keputusan Pembelian Ulang Produk Yakult di Kota Padang. Jurnal Manajemen, 2(1): 1-12. 